Perilaku Makan di Remaja

\title{
Pengaruh Diet Sehat Bagi Penderita Berat Badan Lebih atau Obesitas pada Remaja
}

\author{
Niken Ayunita (1821B0003), Noviyanti Kartika S (1821B0004) \\ STIKes Surya Mitra Husada Kediri \\ Nikenayunita6008@gmail.com, Noviyantikartika6@gmail.com
}

\begin{abstract}
Abstrak
Obesitas merupakan keadaan yang menunjukkan ketidakseimbangan antara tinggi dan berat badan akibat jaringan lemak dalam tubuh sehingga terjadi kelebihan berat badan yang melampaui ukuran ideal. Menurut data Riskesdas 2018 Badan Litbangkes Kementerian Kesehatan menunjukkan prevalensi obesitas meningkat sejak tiga periode yaitu pada tahun 2007 10,5 persen, 2013 14,8 persen, dan 2018 21,8 persen. Dengan permasalahan tersebut diharapkan penderita obesitas melakukan diet sehat agar berat badan mereka bisa terkontrol. Tujuan penelitian ini adalah untuk mengidentifikasi apakah diet sehat berpengaruh terhadap penurunan jumlah penderita obesitas di kalangan remaja. Sasaranya adalah semua remaja yaitu usia 12-21 tahun. Diharapkan dengan adanya diet sehat ini penderita obesitas bisa berkurang.
\end{abstract}

Kata Kunci : Diet Sehat, Obesitas, Remaja

1. Latar Belakang

Makan adalah kegiatan memasukkan makanan atau sesuatu ke dalam mulut untuk menyediakan nutrisi, vitamin dan energi bagi tubuh sehingga tubuh tetap bisa melakukan aktivitas seharihari. Makanan sehat sendiri adalah makanan yang mengandung berbagai nutrisi yang dibutuhkan oleh tubuh 
untuk merawat kesehatan

serta mendukung

pertumbuhan dan

perkembangan. Syarat makanan dikatakan sehat adalah makanan yang bersih, bergizi dan cukup sesuai dengan kebutuhan tubuh. Makanan yang sehat biasanya memiliki kandungan gizi yang seimbang antara karbohidrat, protein, lemak dan vitamin.

Dalam kehidupan sehari hari kita harus makan dengan teratur dan sesuai kebutuhan tubuh sehingga tidak terjadi berat badan lebih atau yang biasa kita sebut obesitas. Seseorang dikatakan obesitas apabila berat badan dan tinggi tubuhnya tidak seimbang akibat penumpukan lemak dalam tubuh. Obesitas merupakan masalah yang cukup merisaukan khusunya dikalangan remaja karena obesitas juga bisa menjadi faktor pemicu terjadinya penyakit hipertensi dan diabetes.

Namun hal tersebut dapat diatasi dengan diet sehat yaitu diet yang dilakukan dengan tujuan memiliki tubuh ideal tanpa menimbulkan efek berbahaya bagi tubuh. Dengan upaya diet sehat tersebut diharapkan angka penderita obesitas menurun sehingga dapat meminimalisir angka kematian akibat obesitas dan tentunya seseorang akan lebih produktif dalam melakukan aktivitas sehari-harinya.

\section{Masalah / Kasus}

Jakarta -Riset Kesehatan Dasar (Riskesdas) 2018 menyatakan prevalensi obesitas atau kegemukan pada orang di atas 18 tahun terus meningkat dari tahun ke tahun sejak 2007. Berdasarkan hasil Riskesdas 2018 Badan Litbangkes Kementerian Kesehatan menunjukkan prevalensi obesitas meningkat sejak tiga periode Riskesdas yaitu pada 200710,5 persen, 201314,8 persen, dan 2018 21,8 persen.

Jumlah tersebut diambil dari hasil survei pada 300 ribu sampel rumah tangga 
di seluruh Indonesia yang dilakukan dalam Riskesdas. Indikator obesitas pada yaitu pada orang dengan indeks massa tubuh (IMT) di atas 27,0. Di mana IMT normal berada pada angka 18,5 sampai 22,9.

Beberapa penelitian menyatakan perkembangan teknologi yang pesat berkontribusi pada peningkatan prevalensi obesitas. "Tanpa disadari teknologi menggiring seseorang untuk bergaya hidup sedentary diantaranya kurang beraktivitas fisik dengan seringnya menggunakan gadget, makan makanan tinggi kalori, dan kurang mengonsumsi buah dan sayur," kata Direktur Utama Prodia, Dewi Muliaty saat acara Inauguration Fat Loss Challenge di La Moda Cafe, Plaza Indonesia, Jakarta, Sabtu (29/12/2018).

\section{Metode}

Metode penelitian yang digunakan adalah penelitian kualitatif yaitu penelitian yang menggali atau ekplorasi, mengembangkan pengetahuan bagaimana kenyataan yang dialami. Dimana populasinya adalah keseluruhan remaja penderita obesitas dengan indikator obesitas yaitu pada orang dengan indeks massa tubuh (IMT) di atas 27,0. Di mana IMT normal berada pada angka 18,5 sampai 22,9 .

\section{Pembahasan}

A. Pengertian Obesitas

Obesitas ialah keadaan yang menunjukkan ketidakseimbangan antara tinggi dan berat badan akibat jaringan lemak dalam tubuh sehingga terjadi kelebihan berat badan yang melampaui ukuran ideal.

Sedangkan menurut Misnadierly 2007, Obesitas adalah kelebihan lemak dalam tubuh, yang umumnya ditimbun dalam jaringan subkutan (bawah kulit), sekitar organ tubuh 
dan kadang terjadi

perluasan ke dalam

jaringan organ.

B. Faktor Penyebab Obesitas

Ada beberapa faktor penyebab obesitas

diantarannya adalah :

Makan berlebih

Makan dalam jumlah

yang berlebihan

merupakan faktor

utama yang

menyebabkan

terjadinnya obesitas

dikarenakan semakin

banyak makanan yang

kita konsumsi maka

semakin besar pula

peluang terjadinya

obesitas apabila kita

tidak

mengimbanginya

dengan olahraga dan

aktivitas fisik.

1.) Kebiasaan mengemil makanan ringan

Mengemil adalah

kebiasaan makan yang

dilakukan di luar

waktu makan, dan

makanan

yang dikonsumsi berupa

makanan kecil yang rasanya gurih, manis dan biasanya digoreng.

Bila kebiasaan ini tidak dikontrol dapat menyebabkan

kegemukan, karena jenis makanan tersebut termasuk makanan tinggi kalori.

2.) Makan dengan tergesa-gesa

Makan secara terburuburu akan menyebabkan efek kurang

menguntungkan bagi pencernaan, karena dapat mengakibatkan rasa lapar kembali setelah makan dan hal tersebut merupakan pemicu terjadinya obesitas.

3.) Kurangnya gerak/ aktivitas

Kurang bergerak atau yang biasa disebut mager, merupakan salah satu faktor penyebab terjadinya 
obesitas dikarenakan

tidak terjadi proses

pembakaran lemak

pada tubuh saat

seseorang hanya diam

dan jarang melakukan

aktivitas.

C. Resiko Penyakit Akibat

Obesitas

Penumpukan lemak tubuh pada penderita obesitas dapat meningkatkan risiko terjadinya gangguan kesehatan serius, seperti penyakit jantung, diabetes, atau hipertensi. Obesitas juga dapat menyebabkan gangguan kualitas hidup dan masalah psikologi, seperti kurang percaya diri hingga depresi. Maka dari itu diperlukan upaya untuk menanggulanggi terjadinya obesitas khusunya pada remaja dengan begitu obesitas tidak akan menimbulkan berbagai resiko penyakit.

D. Diet Sehat

Diet sehat adalah diet yang dilakukan dengan tujuan memiliki tubuh ideal tanpa menimbulkan efek berbahaya bagi tubuh. Berikut ini beberapa cara diet sehat antara lain:

1.) Perhatikan asupan nutrisi

Dalam diet sehat asupan nutrisi sangat diperhatikan. Untuk memenuhi nutrisi pada tubuh disarankan dalam satu hari megkonsumsi 5 porsi buah maupun sayur

2.) Kurangi konsumsi garam.

Mengurangi konsumsi garam merupakan salah satu cara diet sehat yang terkenal ampuh. Karena mengkonsumsi yodium berlebihan bisa menyebabkan tubuh kesulitan untuk memproses metabolisme lemak.

3.) Jadikan apel sebagai camilan wajib.

Sudah tidak asing lagi buah apel sangat 
berkontribusi dalam

proses diet sehat.

Karena dalam sebuah

apel terdapat

kandungan kurang

dari 200 kalori dengan

kandungan protein

dan serat yang tinggi,

sehingga dapat

membantu tubuh

untuk menahan nafsu

makan.

4.) Bakar kalori dengan

rajin olahraga.

Dalam satu hari

setidaknya seseorang

melakukan olahraga

dalam waktu kurang

lebih 15 menit agar

tubuh tetap sehat,

bugar dan jantung

tetap terjaga.

5.) Istirahat yang cukup

Selain memperhatikan

olahraga dan aktivitas

fisik dalam diet sehat

juga disarankan untuk

istirahat yang cukup

yaitu 6 sampai 8 jam

sehari dengan begitu

metabolisme tubuh

akan lancar dan berat badan bias dikontrol

dengan baik dan benar.

E. Manfaat Diet Sehat

Sangat banyak manfaat dari diet sehat selain efektif dalam menurunkan berat badan, diet sehat juga berpengaruh pada kesehatan tubuh. Diet sehat juga jauh lebih aman dibandingkan diet ekstrim lainya yang menyebabkan seseorang jatuh sakit bahkan meninggal. Memang benar dalam proses diet ini dibutuhkan waktu yang cukup lama namun jika kita memang berkomitmen dan bersungguh-sungguh maka berat badan akan turun sehingga penderita obesitas bisa mengontrol berat badanya menuju berat badan yang ideal.

\section{Kesimpulan}

Obesitas adalah ketidak seimbangan berat badan dan tinggi badan yang tejadi karena penumpukan lemak 


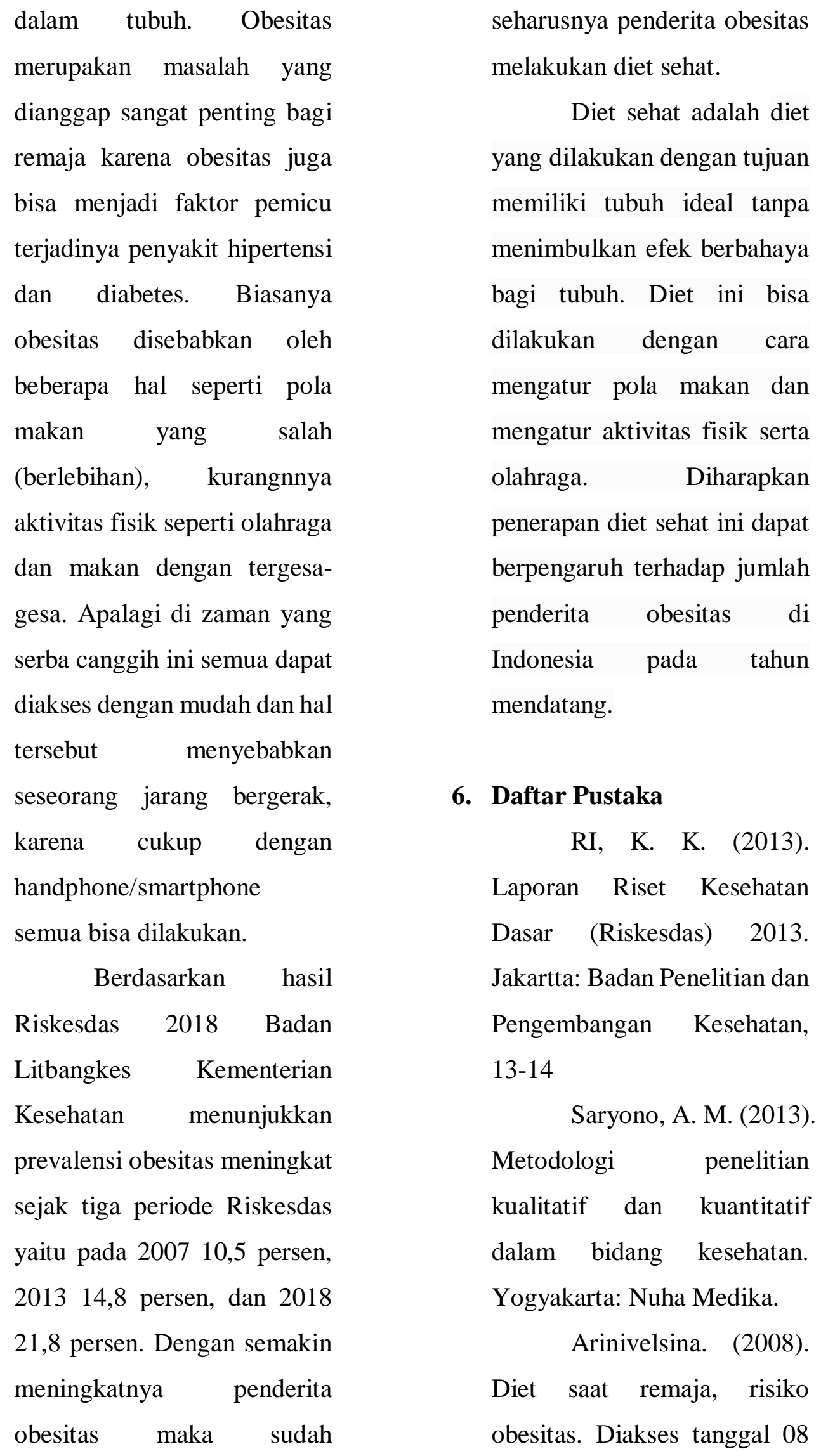


September 2008. dari

http://arinivelsina. multiply.

com/journal/item/20

Misnadiarly. (2007).

Obesitas Sebagai Faktor

Risiko Beberapa Penyakit.

Jakarta: Pustaka Obor Populer.

https://www.alodokter.com/o

besitas

https://lifestyle.sindonews.co

m/read/1366731/155/jumlah-

penderita-obesitas-di-

indonesia-meroket-

1546158368

Mu'tadin, Z. 2002.

Obesitas Dan Faktor

Penyebabnya. Jakarta:

Salemba Medika 